\title{
Heavy metal exposure, in combination with physical activity and aging, is related with oxidative stress in Japanese women from a rural agricultural community
}

\author{
Xiaoyi Cui ${ }^{*}$, Mayumi Ohtsu', Nathan Mise ${ }^{1}$, Akihiko Ikegami ${ }^{1}$, Atsuko Mizuno², Takako Sakamoto',
} Masanori Ogawa', Munehito Machida ${ }^{1}$ and Fujio Kayama ${ }^{1,3}$

\begin{abstract}
This study aimed to evaluate the relationships between oxidative stress and heavy metal exposure (lead [Pb] and cadmium [Cd]), as well as co-factors such as physical activity and age, in Japanese women. This study was conducted with female subjects from a rural agricultural community in Japan. Subjects were asked to complete lifestyle-related questionnaires and undergo a group health examination. Physical activity, alcohol consumption, body mass index, and other demographic information were collected. Blood and urine samples were collected to measure urinary 8-hydroxydeoxyguanosine (8-OHdG) levels and blood and urinary $\mathrm{Cd}$ and $\mathrm{Pb}$ concentrations. Urine samples were analyzed using high performance liquid chromatography and flameless atomic absorption spectrometry; blood samples were analyzed using inductively coupled plasma-mass spectrometry. Age, physical activity, and blood and urinary $\mathrm{Cd}$ and $\mathrm{Pb}$ concentrations were included in structural equation modeling analysis. Two latent factors for heavy metal exposure and physical activity were produced to predict the total influence of the variables. The final model was good: $\mathrm{CMIN} / \mathrm{DF}=0.775, \mathrm{CFI}=1.000, \mathrm{GFI}=0.975, \mathrm{AGFI}=0.954, \mathrm{RMSEA}=0.000 .8-\mathrm{OHdG}$ levels were positively associated with heavy metal exposure, physical activity, and age (standard $\beta$ of path analysis: $0.33,0.38$, and 0.20 , respectively). Therefore, oxidative stress is associated with both, environmental and lifestyle factors, in combination with aging.
\end{abstract}

Keywords: Lead, Cadmium, Oxidative stress, Physical activity, Aging, Japanese female population

\section{Background}

Oxidative stress can be defined as an excessive amount of reactive oxygen species (ROS), that overwhelm the innate antioxidant protection of the body and lead to oxidative damage to DNA, resulting in detrimental effects on health (Kohen and Nyska 2002; Poljsak et al. 2013). 8-hydroxy-2'-deoxyguanosine (8-OHdG), or 8-oxo7,8-dihydro-2'-deoxyguanosine (8-oxodG), is considered to be a critical biomarker of oxidative stress and is a major product of oxidative DNA damage (Cheng et al.

\footnotetext{
*Correspondence: xiaoyicui0508@gmail.com

1 Department of Environmental and Preventive Medicine, Jichi Medical University, 3311-1, Yakushiji, Shimotsuke, Tochigi 329-0498, Japan Full list of author information is available at the end of the article
}

1992; Valavanidis et al. 2009). Urinary 8-OHdG has been reported a good biomarker for and estimator of oxidative stress in humans after exposure to heavy metals (Pizzino et al. 2014; Valavanidis et al. 2009). In addition, urinary 8-OHdG could act as a prospective biomarker for the prediction of lifestyle-related diseases (Sakano et al. 2009).

A number of studies have investigated the effect of the heavy metals cadmium $(\mathrm{Cd})$ and lead $(\mathrm{Pb})$ on oxidative stress (Cuypers et al. 2010; Ercal et al. 2001; Flora et al. 2008; Mikhailova et al. 1997). In humans, Cd exposure occurs from cigarette smoking, air contamination, water, and food and has negative effects on human health owing to the low excretion rate and accumulation in the organs 
(Bertin and Averbeck 2006). The biologic half-life of $\mathrm{Cd}$ in the kidney may be up to 38 years (Agency for Toxic Substances and Disease Registry 2008). Previous studies with humans have also shown increased 8-OHdG concentrations associated with $\mathrm{Cd}$ exposure, with a strong association between urinary $\mathrm{Cd}$ and 8-OHdG (Engström et al. 2010). $\mathrm{Pb}$ is maintained in the environment; therefore, exposure to $\mathrm{Pb}$ can occur through various sources such as food, drinking water, and air contamination. No safe level of exposure to $\mathrm{Pb}$ has been identified. Various mechanisms have been found to explain $\mathrm{Pb}$ toxicity, and oxidative stress has been reported as a major mechanism of Pb-induced toxicity (Flora et al. 2012). The inhibitory effects of $\mathrm{Pb}$ on antioxidant enzymes render cells more susceptible to oxidative stress (Ercal et al. 2001).

A number of factors have been associated with oxidative stress. For example, oxidative stress increases during aging, and there is sufficient evidence that 8-OHdG might be a useful indicator of age-related oxidative stress (Mecocci et al. 1993; Wolf et al. 2005). In other studies, moderate exercise was associated with reduced 8-OHdG level, while smoking and long working hours were associated with increased 8-OHdG levels, suggesting that many lifestyle factors may affect oxidative stress (Irie et al. 2005; Kasai et al. 2001). We hypothesized that low and chronic exposure to the heavy metals $\mathrm{Cd}$ and $\mathrm{Pb}$ and the concurrent presence of lifestyle factors and older age are related with oxidative stress. Therefore, this study aimed to investigate the relationships between oxidative stress and heavy metal exposure as well as other co-factors and to determine if the associated risk factors could influence 8-OHdG concentrations, on an individual and/or concurrent basis.

\section{Methods}

\section{Subjects}

This study was conducted with female subjects from an agricultural community in a district in the north of Kyushu Island in 2001 as part of the Japanese Multi-centered Environmental Toxicant Study (JMETS). Additional details about the JMETS are reported elsewhere (Horiguchi et al. 2004a, 2005). The volunteer sampling method was used for the study. The subjects were asked to participate in the study through the local Agricultural Cooperative. The study area has a relatively low exposure to $\mathrm{Cd}$ and $\mathrm{Pb}$, and the JMETS also demonstrated a relatively low exposure to $\mathrm{Cd}$ through rice. The subjects were farmers or family members of farmers who had consumed locally produced foods and rice and vegetables grown in their own fields since birth. Most of the residents had graduated high school, at most. The younger generation had completed higher education, such as junior college.

\section{Questionnaires and data collection}

We held group orientations for the study subjects, during which we explained the study purpose and protocol and obtained written informed consent from each subject. The subjects completed the questionnaires after receiving an explanation from trained public health nurses. At the health examinations, we measured the subjects' weight and height. Body mass index (BMI) was calculated using body weight and height.

Two questionnaires were completed. The first collected general information about socio-demographic characteristics, history of present or previous disease, smoking status, and self-reported amount of daily/weekly physical activity, categorized as voluntary exercise (consisting of moderate exercise, vigorous exercise, resistance training, and bicycle riding or walking), general everyday activities (consisting of meals, watching TV or reading, driving an automobile, and interesting activities at home), or activity at work (consisting of desk work, strenuous housework, active work, and carpentry work). We recorded the amount of weekly physical activity because many of the female subjects did not participate in voluntary exercise on a daily basis. The second questionnaire was a self-administered diet history questionnaire (DHQ) developed by Sasaki et al. (1998). Briefly, the DHQ was designed to determine food and nutrient intakes in the previous month in Japan. It has been validated and used in many epidemiological studies (Kobayashi et al. 2011). Alcohol consumption status was determined using the DHQ.

\section{Sample analysis}

We collected peripheral blood and second-morning urine samples before breakfast. The whole blood samples were digested with nitric acid by a microwave device (MDS200, CEM), after which blood $\mathrm{Cd}$ and $\mathrm{Pb}$ levels were measured using inductively coupled plasma-mass spectrometry (HP 4500 series; Yokokawa Analytical Systems, Tokyo, Japan). Urinary $\mathrm{Cd}$ and $\mathrm{Pb}$ levels were measured using flameless atomic absorption spectrometry (SIMAA 6000; Perkin Elmer, Japan). The urine samples were analyzed for 8-OHdG using the HPLC-CoulArray system (ESA Inc. USA). 8-OHdG stock standards were produced from 8-hydroxy-2'-deoxyguanosine (purity 99\%, ESA, ECR703391). Urinary creatinine (Cr) was measured using the Jaffe reaction method (DIA-IATRON). The analytic value of urine samples was adjusted for $\mathrm{Cr}$.

\section{Statistical analysis}

Demographic variables were divided into groups based on age $(<50,50-59$, and $\geq 60$ years $)$, BMI $(<18.5,18.5-$ 24.9 , and $\geq 25 \mathrm{~kg} / \mathrm{m}^{2}$ ), smoking status (smokers and 
non-smokers), and alcohol consumption status (alcohol consumption, no alcohol consumption, previous alcohol consumption). Additionally, the 8-OHdG values were divided into four categories based on the 25th, 50th, and 75 th percentiles. Non-parametric tests were performed for the variables that were not normally distributed over all groups or in each group (Shapiro-Wilk test, $\mathrm{p}<0.05$ ). The non-parametric Spearman's correlation analysis was used to evaluate the relationships between 8-OHdG and the variables that were not distributed, including age, BMI, physical activity, and heavy metal exposure. The non-parametric Kruskal-Wallis test or Mann-Whitney test was performed to compare the median values of 8-OHdG between different demographic variable groups and median age and physical activity between different 8-OHdG categories. Heavy metal exposure variables were log-transformed to follow the approximate normal distribution to compare the geometric means (GMs). The GMs of heavy metal exposure and mean of BMI were compared between the 8-OHdG categories using the parametric analysis of variance (ANOVA) or Student's $t$ tests. To explore the causal relationship between heavy metal exposure, physical activity, age, and 8-OHdG, structural equation modeling (SEM) was used. We produced two latent factors for heavy metal exposure and physical activity to predict the total influence of the variables. All analyses were conducted using SPSS ver 19 (IBM Corp., Armonk, NY) and AMOS ver 20 (IBM Corp., Armonk, $\mathrm{NY}$ ). A $\mathrm{p}<0.05$ was considered statistically significant.

\section{Results}

After excluding 14 subjects (missing questionnaire data, $\mathrm{n}=6$; missing $\mathrm{Cd}$ concentration data for urine samples, $\mathrm{n}=2$; missing $\mathrm{Cd}$ concentration date for blood sample, $\mathrm{n}=1$; missing 8 -OHdG concentration data for urine samples, $\mathrm{n}=4$; and colon cancer; $\mathrm{n}=1$ ) from the potential 202 subjects, the sample consisted of 188 subjects. Obesity (BMI $\geq 25 \mathrm{~kg} / \mathrm{m}^{2}$ ) was present in $34.0 \%$ $(\mathrm{n}=64)$ of the subjects, and $2.7 \%(\mathrm{n}=5)$ of the subjects were smokers. We did not find a significant association between smoking status and 8-OHdG levels, potentially owing to the small number of smokers. Higher levels of 8-OHdG were found in older age groups (Table 1). The GMs of the blood $\mathrm{Pb}$ and $\mathrm{Cd}$ concentrations were 14.42 and $1.99 \mu \mathrm{g} / \mathrm{L}$, respectively, and the GMs of the urinary $\mathrm{Pb}$ and $\mathrm{Cd}$ concentrations were 1.12 and $3.51 \mu \mathrm{g} / \mathrm{g} \mathrm{Cr}$, respectively. The correlations between each variable and 8-OHdG as well as the comparisons of the distribution for each variable between the 8-OHdG categories are shown in Table 2. The Spearman's correlations between 8-OHdG and age, blood $\mathrm{Pb}$ concentration, urinary $\mathrm{Pb}$ concentration, urinary $\mathrm{Cd}$ concentration, vigorous exercise, bicycle riding or walking, and driving an automobile
Table 1 Characteristics of and 8-hydroxydeoxyguanosine (8-OHdG) levels in female subjects

\begin{tabular}{|c|c|c|c|}
\hline \multirow[t]{2}{*}{ Variables } & \multicolumn{3}{|c|}{ 8-OHdG (ng/mg Cr) } \\
\hline & n (\%) & Median (min-max) & $p^{a}$ \\
\hline \multicolumn{4}{|l|}{ Age (years) } \\
\hline$<50$ & $39(20.7 \%)$ & $3.30(1.11-14.80)$ & \\
\hline $50-59$ & $72(38.3 \%)$ & $5.03(1.48-18.21)$ & \\
\hline$\geq 60$ & $77(41.0 \%)$ & $6.56(1.41-14.41)$ & $0.00^{\mathrm{a}}$ \\
\hline \multicolumn{4}{|l|}{ BMI $\left(\mathrm{kg} / \mathrm{m}^{2}\right)$} \\
\hline$<18.5$ & $3(1.6 \%)$ & $8.15(3.07-9.88)$ & \\
\hline $18.5-24.9$ & $121(64.4 \%)$ & $5.33(1.11-14.80)$ & \\
\hline$\geq 25$ & $64(34.0 \%)$ & $5.01(1.48-18.21)$ & $0.73^{\mathrm{a}}$ \\
\hline \multicolumn{4}{|l|}{ Smoking status } \\
\hline Smoker & $5(2.7 \%)$ & $5.09(1.64-14.80)$ & \\
\hline Non-smoker & $183(97.3 \%)$ & $5.26(1.11-18.21)$ & $0.76^{b}$ \\
\hline \multicolumn{4}{|c|}{ Alcohol consumption status } \\
\hline Alcohol consumption & $76(40.4 \%)$ & $5.12(1.41-11.39)$ & \\
\hline No alcohol consumption & $110(58.5 \%)$ & $5.36(1.11-18.21)$ & \\
\hline $\begin{array}{l}\text { Previous alcohol } \\
\text { consumption }\end{array}$ & $2(1.1 \%)$ & $4.84(4.33-5.36)$ & $0.39^{a}$ \\
\hline Total & 188 (100\%) & $5.25(1.11-18.21)$ & \\
\hline
\end{tabular}

a Median 8-hydroxydeoxyguanosine (8-OHdG) values were compared between age $(<50,50-59, \geq 60$ years), body mass index (BMI) $(<18.5,18.5-24.9, \geq 25 \mathrm{~kg} /$ $\mathrm{m}^{2}$ ), and alcohol consumption (alcohol consumption, no alcohol consumption, previous alcohol consumption) groups using Kruskal-Wallis tests

b Median 8-OHdG values were compared between the smoking status (smoker and non-smoker) groups using Mann-Whitney tests

were significant. Among these variables, driving an automobile was negatively associated with 8 -OHdG, while the remaining variables were positively associated with 8-OHdG. There were significant differences in blood $\mathrm{Pb}$, urinary $\mathrm{Pb}$, and urinary $\mathrm{Cd}$ concentrations between the four 8-OHdG categories, based on the ANOVA test. There were also significant differences in age, bicycle riding or walking, and driving an automobile between the four 8-OHdG categories, based on the Kruskal-Wallis test. Additionally, significant differences in bicycle riding or walking, watching TV or reading, and strenuous housework were observed between the $>75$ th percentile and 51-75th percentile 8-OHdG categories, based on the Mann-Whitney $U$ test. Between the $>75$ th percentile and 26-50th percentile 8-OHdG categories, significant differences were found in urinary $\mathrm{Pb}$ concentrations, urinary $\mathrm{Cd}$ concentrations, and driving an automobile. Between the $>75$ th percentile and $\leq 25$ th percentile 8 -OHdG categories, significant differences were found in age, blood $\mathrm{Pb}$ concentrations, urinary $\mathrm{Cd}$ concentrations, bicycle riding or walking, and driving an automobile (Table 2). The subjects had limited participation in physical activity including moderate exercise, vigorous exercise, resistance training, and carpentry work, resulting in a median 
Table 2 Comparison of variables by quartiles of urinary 8-hydroxydeoxyguanosine (8-OHdG) and correlations of the variables with 8-OHdG levels

\begin{tabular}{|c|c|c|c|c|c|c|c|}
\hline \multirow[t]{4}{*}{ Variables } & \multicolumn{7}{|c|}{ Quartiles of 8-OHdG values } \\
\hline & $\leq 25$ th percentile & $\begin{array}{l}\text { 26-50th percen- } \\
\text { tiles }\end{array}$ & $\begin{array}{l}51-75 \text { th percen- } \\
\text { tiles }\end{array}$ & $>75$ th percentile & Total & $\mathbf{p}$ & $R^{c}$ \\
\hline & $\leq 3.68(n=47)$ & $3.68-5.25(n=47)$ & $5.25-7.47(n=47)$ & $>7.47(n=47)$ & $(n=188)$ & & \\
\hline & $\begin{array}{l}\text { Mean (SD), GM } \\
\text { (GSD), or median } \\
\text { (min-max) }\end{array}$ & $\begin{array}{l}\text { Mean (SD), GM } \\
\text { (GSD), or median } \\
\text { (min-max) }\end{array}$ & $\begin{array}{l}\text { Mean (SD), GM } \\
\text { (GSD), or median } \\
\text { (min-max) }\end{array}$ & $\begin{array}{l}\text { Mean (SD), GM } \\
\text { (GSD), or median } \\
\text { (min-max) }\end{array}$ & $\begin{array}{l}\text { Mean (SD), GM } \\
\text { (GSD), or median } \\
\text { (min-max) }\end{array}$ & & \\
\hline Age $(\text { years })^{f}$ & $50(39-72)$ & $56(35-75)$ & $62(38-77)$ & $63(47-73)^{\triangle}$ & $57(35-77)$ & $0.00^{b}$ & $0.35^{*}$ \\
\hline $\operatorname{BMI}\left(\mathrm{kg} / \mathrm{m}^{2}\right)^{\mathrm{d}}$ & $23.70(2.72)$ & $24.03(3.14)$ & $24.18(2.93)$ & $23.60(2.97)$ & $23.88(2.93)$ & $0.75^{\mathrm{a}}$ & 0.02 \\
\hline Blood lead $(\mu \mathrm{g} / \mathrm{L})^{\mathrm{e}}$ & $13.43(1.04)$ & $14.02(1.05)$ & $14.18(1.04)$ & $16.19(1.06)^{\triangle}$ & $14.42(1.02)$ & $0.04^{\mathrm{a}}$ & $0.18^{*}$ \\
\hline $\begin{array}{l}\text { Urinary lead } \\
(\mu \mathrm{g} / \mathrm{g} C r)^{e}\end{array}$ & $1.06(1.08)$ & $1.01(1.06)$ & $1.11(1.05)$ & $1.32(1.08)^{h^{4}}$ & $1.12(1.04)$ & $0.03^{\mathrm{a}}$ & $0.20^{*}$ \\
\hline $\begin{array}{l}\text { Blood cadmium } \\
(\mu \mathrm{g} / \mathrm{L})^{\mathrm{e}}\end{array}$ & $2.06(1.08)$ & $1.94(1.07)$ & $2.09(1.06)$ & $1.87(1.06)$ & $1.99(1.03)$ & $0.58^{\mathrm{a}}$ & -0.08 \\
\hline $\begin{array}{l}\text { Urinary cadmium } \\
(\mu \mathrm{g} / \mathrm{g} \mathrm{Cr})^{\mathrm{e}}\end{array}$ & $3.27(1.08)$ & $2.99(1.09)$ & $3.90(1.06)$ & $4.00(1.07)^{n}$ & $3.51(1.04)$ & $0.01^{\mathrm{a}}$ & $0.22^{*}$ \\
\hline \multicolumn{8}{|c|}{ Physical activity (min/week) $)^{f}$} \\
\hline \multicolumn{8}{|l|}{ Voluntary exercise } \\
\hline Moderate exercise & $0(0-480)$ & $0(0-900)$ & $0(0-960)$ & $0(0-1440)$ & $0(0-1440)$ & $0.85^{b}$ & 0.02 \\
\hline Vigorous exercise & $0(0-120)$ & $0(0-0)$ & $0(0-360)$ & $0(0-630)$ & $0(0-630)$ & $0.09^{b}$ & $0.15^{*}$ \\
\hline Resistance training & $0(0-120)$ & $0(0-0)$ & $0(0-240)$ & $0(0-0)$ & $0(0-240)$ & $0.14^{b}$ & -0.07 \\
\hline $\begin{array}{l}\text { Bicycle riding or } \\
\text { walking }\end{array}$ & $0(0-800)$ & $70(0-500)$ & $0(0-1800)$ & $120(0-700)^{\diamond} \triangle$ & $40(0-1800)$ & $0.01^{b}$ & $0.19^{*}$ \\
\hline \multicolumn{8}{|c|}{ General everyday activities } \\
\hline Meals & 420 (200-1050) & $430(0-1100)$ & $450(70-1260)$ & $420(180-1800)$ & $420(0-1800)$ & $0.72^{b}$ & -0.05 \\
\hline $\begin{array}{l}\text { Watching TV or } \\
\text { reading }\end{array}$ & $1050(70-5400)$ & $1050(150-2940)$ & $840(70-5400)$ & $1380(100-7200)^{\diamond}$ & $1050(70-7200)$ & $0.11^{b}$ & 0.12 \\
\hline $\begin{array}{l}\text { Driving an automo- } \\
\text { bile }\end{array}$ & $260(0-4480)$ & $210(0-3000)$ & $200(0-1000)$ & $200(0-5400)^{\sqrt{4} \Delta}$ & $210(0-5400)$ & $0.01^{b}$ & $-0.24^{*}$ \\
\hline $\begin{array}{l}\text { Interesting activities } \\
\text { at home }\end{array}$ & $1050(70-3780)$ & $1050(0-6000)$ & $840(0-2800)$ & $1200(0-4200)$ & $1050(0-6000)$ & $0.41^{b}$ & -0.05 \\
\hline \multicolumn{8}{|l|}{ Activity at work } \\
\hline Desk work & $60(0-4100)$ & $300(0-2940)$ & $0(0-3960)$ & $140(0-7200)$ & $60(0-7200)$ & $0.15^{\mathrm{b}}$ & -0.05 \\
\hline $\begin{array}{l}\text { Strenuous house- } \\
\text { work }\end{array}$ & $140(0-1200)$ & $105(0-840)$ & $60(0-630)$ & $150(0-3600)^{\diamond}$ & $120(0-3600)$ & $0.06^{b}$ & 0.01 \\
\hline Active work & $60(0-3360)$ & $120(0-2520)$ & $0(0-3360)$ & $180(0-2520)$ & $75(0-3360)$ & $0.83^{b}$ & -0.01 \\
\hline Carpentry work & $0(0-240)$ & $0(0-540)$ & $0(0-300)$ & $0(0-210)$ & $0(0-540)$ & $0.48^{b}$ & -0.10 \\
\hline
\end{tabular}

* $p<0.05$ based on the Spearman's rank correlation analysis

$\diamond \mathrm{p}<0.05$ for the comparisons of the mean and GM using Student's $t$ test or the median using Mann-Whitney U tests between the $>75$ th and $51-75$ th percentile categories

it $\mathrm{p}<0.05$ for the comparisons of the mean and GM using Student's $t$ test or the median using Mann-Whitney U tests between the $>75$ th and $26-50$ th percentile categories

$\triangle p<0.05$ for the comparisons of the mean and GM using Student's $t$ test or the median using Mann-Whitney $U$ tests between the $>75$ th and $\leq 25$ th percentile categories

a Mean body mass index (BMI) and the geometric mean (GM) of the heavy metal exposure variables were compared between the 4 quartile categories of 8-OHdG using ANOVA tests

b Median age and physical activity were compared between the 4 quartile groups of 8-OHdG using Kruskal-Wallis tests

c Spearman's rank correlation coefficient between 8-OHdG and each variable

d Results shown as mean (standard deviation [SD])

e Results shown as GM (geometric standard deviation [GSD])

f Results shown as median (min-max) 
of $0 \mathrm{~min} /$ week for the four 8-OHdG categories. We did not exclude the 'Vigorous exercise' item, which was significantly correlated with 8-OHdG, in the further analysis despite the limited involvement in this type of physical activity, because it was the most interesting observation.

Based on our hypothesis, we created an SEM model using all the heavy metal exposure variables and other variables that were significantly correlated with $8-\mathrm{OHdG}$ or were significantly different between the 8-OHdG categories, as reported in Table 2. Although some of the correlations between these variables and 8-OHdG were poor, the maintenance of these correlations could be determined when the variables were combined with other co-factors in the SEM analysis. Based on the modification indices in AMOS, we deleted some correlation paths if the explanatory variable was unrelated. The final model was good: CMIN/ $\mathrm{DF}=0.775$, CFI $=1.000$, GFI $=0.975$, AGFI $=0.954$, RMSEA $=0.000$. The standardized regression coefficients of the variables used in the path models are shown in Table 3. The latent variables of 'Heavy metal exposure' and 'Physical activity' were positively associated with 8 -OHdG levels $(\beta=0.33$ and 0.38 , respectively). The observed variable age was positively associated with 8 -OHdG levels $(\beta=0.20)$. The latent variable of 'Heavy metal exposure' was positively associated with urinary $\mathrm{Cd}$ concentrations and blood $\mathrm{Pb}$ concentrations ( $\beta=0.53$ and 0.80 , respectively) and negatively associated with blood $\mathrm{Cd}$ concentrations $(\beta=-0.53)$. Urinary lead significant positive associated with 8-OHdG, but lost significance in SEM model. The latent variable of 'Physical activity' was positively associated with vigorous exercise, watching TV or reading, and strenuous housework

\begin{tabular}{|c|c|c|c|}
\hline Dependent variable & Independent variable & Standard $\beta$ & $\mathrm{p}$ \\
\hline \multirow{3}{*}{$\begin{array}{l}\text { 8-OHdG (measured vari- } \\
\text { able) }\end{array}$} & Heavy metal exposure & 0.33 & $-^{\mathrm{a}}$ \\
\hline & Physical activity & 0.38 & $-^{\mathrm{a}}$ \\
\hline & Age & 0.20 & 0.00 \\
\hline \multirow{4}{*}{$\begin{array}{l}\text { Heavy metal exposure } \\
\text { (latent variable) }\end{array}$} & Urinary cadmium & 0.53 & 0.01 \\
\hline & Blood cadmium & -0.53 & 0.01 \\
\hline & Urinary lead & -0.02 & 0.94 \\
\hline & Blood lead & 0.80 & 0.00 \\
\hline \multirow{5}{*}{$\begin{array}{l}\text { Physical activity (latent } \\
\text { variable) }\end{array}$} & Vigorous exercise & 0.40 & 0.02 \\
\hline & Bicycle riding or walking & -0.09 & 0.60 \\
\hline & Watching TV or reading & 0.82 & 0.00 \\
\hline & Driving an automobile & -0.27 & 0.13 \\
\hline & Strenuous housework & 0.37 & 0.02 \\
\hline
\end{tabular}

${ }^{a} \mathrm{p}$ values could not be calculated because the independent variable was a latent variable
( $\beta=0.40,0.82$, and 0.37 , respectively) in the SEM analysis. Significant positive and negative correlations were present between 8-OHdG and bicycle riding or walking and driving an automobile, respectively, in the correlation analyses; however, the correlations were no longer significant in the final SEM model (Table 3). Additionally, significant correlation coefficient estimates $(\mathrm{p}<0.05)$ were observed in the SEM analysis between the explanatory variables 'urinary cadmium' and 'blood cadmium' ( $r=0.35)$, 'urinary lead' and 'blood lead' $(r=0.29)$, 'urinary cadmium' and 'age' $(r=0.34)$, 'vigorous exercise' and 'bicycle riding or walking' $(r=0.27)$, 'vigorous exercise' and 'watching TV or reading' $(r=0.15)$, 'vigorous exercise' and 'strenuous housework' $(r=0.17)$, 'bicycle riding or walking' and 'age' $(r=0.16)$, 'driving an automobile' and 'age' $(\mathrm{r}=-0.16)$, 'watching TV or reading' and 'driving an automobile' $(\mathrm{r}=0.40)$ (Fig. 1).

\section{Discussion}

We hypothesized that heavy metal exposure and other co-factors might be related with oxidative stress. We conducted a study to evaluate 8-OHdG, heavy metal (including $\mathrm{Pb}$ and $\mathrm{Cd}$ ) exposure, physical activity, smoking status, age, and other factors in a regional Japanese female population.

Our research suggests that continuous exposure to heavy metals increases oxidative stress. Urinary $\mathrm{Pb}$, blood $\mathrm{Pb}$, and urinary $\mathrm{Cd}$ concentrations were significantly correlated with 8-OHdG concentrations. By including other co-factors in the final SEM analysis, blood Pb concentrations and urinary $\mathrm{Cd}$ concentrations were significantly and positively association with the 'Heavy metal exposure' variable ( $\beta=0.80$ and 0.53 , respectively), which positively indicated the urinary $8-\mathrm{OHdG}$ concentration. Diagnosis of $\mathrm{Pb}$ exposure is mainly based on blood $\mathrm{Pb}$ levels, it is the best available marker of current and recent $\mathrm{Pb}$ exposure (Lowry 2010), and the adverse health effects have been observed with varying blood $\mathrm{Pb}$ levels, from low to high (Perth District Health Unit 2014). In the SEM analysis, urinary $\mathrm{Pb}$ concentrations were no longer significant, and blood $\mathrm{Pb}$ concentrations were significantly associated with 'Heavy metal exposure', which could indicate that blood $\mathrm{Pb}$ concentrations have a stronger positive effect for 'Heavy metal exposure.' A previous study indicated that blood $\mathrm{Cd}$ concentrations are mainly influenced by the last few months of exposure and less by the body burden in the general population without occupational exposure (Lauwerys et al. 1994). The subjects in this study did not have occupational exposure, and most of the subjects were non-smokers (97.3\%); therefore, food was likely the major source of $\mathrm{Cd}$ exposure. $\mathrm{Cd}$ absorption can be affected by many factors such as age, sex, and nutritional status, and higher $\mathrm{Cd}$ absorption rates were previously found with younger age in both animal and human studies (Engström 


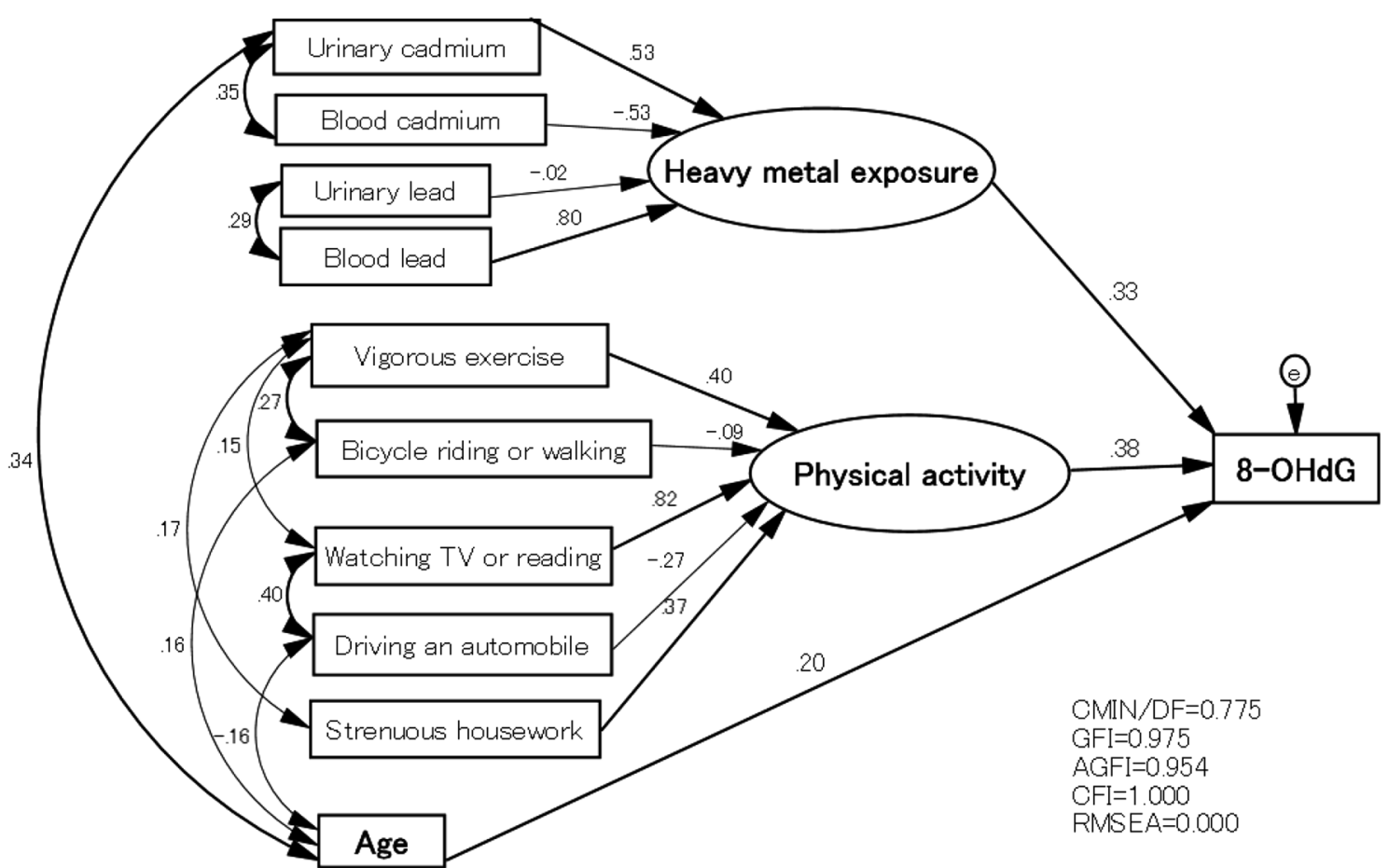

Fig. 1 Results of the structural equation modeling (SEM) analysis. The standard $\beta$ analysis result produced by Amos: the standard $\beta$ from Heavy metal exposure, Physical activity, and Age for $8-\mathrm{OHdG}$ are $0.33,0.38$, and 0.20 , respectively. The model fit test result produced by Amos: CMIN/DF (Chi square/degree of freedom ratio) $=0.775$, CMIN/DF ratio values $<2$ are widely considered to represent a minimally plausible model; $C F I$ (comparative fix index) $=1.000$, close to 1 indicates a very good fit; GFI (Goodness of Fit Index) $=0.975$, GFI > 0.95 indicates a good fit; AGFI (adjusted $\mathrm{GFI})=0.954, \mathrm{AGFI}>0.9$ indicates a good fit; RMSEA (root mean square error of approximation) $=0.000$, there is good model fit if RMSEA is $\leq 0.05$

and Nordberg 1979; Horiguchi et al. 2004b). In the present study, blood $\mathrm{Cd}$ concentrations were not correlated with 8-OHdG and were negatively associated with 'Heavy metal exposure' in the SEM analysis, this result could be indirectly affected by other co-factors such as age, which was significantly correlated with 8-OHdG. Further studies are necessary to elucidate these relationships. The urinary $\mathrm{Cd}$ concentration is a useful estimate for long-term chronic Cd exposure and total body burden (Järup 2002). In the present study, 8-OHdG and urinary $\mathrm{Cd}$ concentrations were significantly correlated. A study among women also found a significant correlation between 8-OHdG levels and urinary $\mathrm{Cd}$ concentrations, but not with blood $\mathrm{Cd}$ concentrations, indicating that oxidative stress might be affected by long-term $\mathrm{Cd}$ retention rather than short-term exposure (Engström et al. 2010). In the SEM analysis, urinary $\mathrm{Cd}$ concentrations positively affected the 'Heavy metal exposure' variable, even when combined with age and other factors, indicating that urinary $\mathrm{Cd}$ concentration is a useful $\mathrm{Cd}$ exposure index for oxidative stress, supporting the findings of a previous study in which urinary 8 -OHdG concentrations were correlated with urinary $\mathrm{Cd}$ concentrations $(\mathrm{r}=0.46, \mathrm{p}<0.0001)$ and with the combined exposure index (Pizzino et al. 2014).
We found that oxidative stress-related 8-OHdG levels increased with age, which confirmed the findings of the study by Muller et al. (2007). Another study in Japanese women found an association between reductions in BMI and elevated urinary 8-OHdG levels (Mizoue et al. 2006). A tendency for higher 8-OHdG levels in subjects with BMIs $<18.5 \mathrm{~kg} / \mathrm{m}^{2}$ was found in the present study; however, this was not statistically significant because of the small sample size. Tobacco smoking was not significantly associated with 8-OHdG values because most of the female subjects were not smokers. Exercise is associated with increased free radical production and ROS generation, and intensity is a critical factor in exercise-induced oxidative stress (Davies et al. 1982; McBride et al. 1998). In the present study, intense physical activity such as vigorous exercise (standard $\beta=0.40$ ) and strenuous housework (standard $\beta=0.37$ ), which positively indicated 'Physical activity', also positively indicated the 8-OHdG concentrations. Sedentary behavior, which includes TV viewing and reading, has been identified as an independent risk factor for several diseases (Wilmot et al. 2012). Previous studies suggested that sedentary lifestyle is a high-risk behavior which might result in low shear stress, leading to ROS generation and increased oxidative stress 
(Szostak and Laurant 2011; Takahashi et al. 2015; Thosar et al. 2012). In the present study, we found that the sedentary behavior of 'watching TV or reading' positively indicated 'Physical activity', which also positively indicated the 8-OHdG concentrations (standard $\beta=0.82$ ), supporting the findings of the previous studies. Bicycle riding or walking and driving an automobile were significantly associated with 8-OHdG in the correlation analyses, but not in the final SEM analysis. It is noteworthy that significant positive or negative correlations were present between these two variables and the co-factor 'age' in the SEM analysis. Therefore, the association between these variables and 8-OHdG were more convincing in the SEM models, when they were combined with other confounding factors.

Furthermore, 8-OHdG has been analyzed using both high performance liquid chromatography (HPLC) and enzyme-linked immunosorbent assay (ELISA) methods (Tamae et al. 2009; Witherell et al. 1998). The mean 8-OHdG concentration in the present study $(5.78 \pm 2.91 \mathrm{ng} / \mathrm{mg} \mathrm{Cr})$ was lower than that determined previously using ELISA (Saito et al. 2013; Shimoi et al. 2002; Witherell et al. 1998). The limitation of this study is that the region is in an agricultural area of Japan, most of the subjects were farmers or housewives, and the subjects spent more time being physically active during their general everyday activities at home and doing strenuous housework than during voluntary exercise and doing carpentry work.

\section{Conclusion}

In summary, we hypothesized that heavy metal exposure and the concurrent presence of lifestyle factors and age are related with oxidative stress. The most positive associations with 8-OHdG were present for several items of heavy metal exposure (urinary $\mathrm{Cd}$ concentrations and blood $\mathrm{Pb}$ concentrations), physical activity (vigorous exercise, watching TV or reading, and strenuous housework), and age. The findings of this study suggest that oxidative stress is related with exposure to heavy metals such as $\mathrm{Pb}$ and $\mathrm{Cd}$, and physical activity in combination with aging. It is important to reduce chronic heavy metal exposure and manage lifestyle factors during aging to prevent the adverse health effects caused by oxidative stress. Further studies with other female populations with different lifestyles and heavy metal exposure levels are required to confirm and strengthen our findings.

\section{Authors' contributions}

The study was designed by FK and XC. The sample collection and analysis were performed by FK. The statistical analysis was performed by XC. Final manuscript was drafted and edited by $X C$, and the manuscript was revised by $M O, N M, A l, A M, T S, M O, M M, F K$. All authors read and approved the final manuscript.

\begin{abstract}
Author details
${ }^{1}$ Department of Environmental and Preventive Medicine, Jichi Medical University, 3311-1, Yakushiji, Shimotsuke, Tochigi 329-0498, Japan. ${ }^{2}$ Department of Pharmacology, Jichi Medical University, Shimotsuke, Tochigi, Japan. ${ }^{3}$ Core Research for Evolutional Science and Technology, Japan Science and Technology Agency (CREST-JST), Tokyo, Japan.
\end{abstract}

\section{Acknowledgements}

We would like to express special gratitude to JA Kitakyushu for their help recruiting their female members. We also acknowledge the contributions from and dedication of Dr. Hyogo Horiguchi and Mrs. Etsuko Oguma. We sincerely thank Dr. Hiroshi Kasai for his excellent advice for the measurement of 8-OHdG and Mrs. Namiko Kanamori for her technical skill in measuring 8-OHdG.

\section{Competing interests}

The authors declare that they have no competing interests.

\section{Compliance with ethical standards}

The survey was reviewed and approved by the Ethical Committee of the Japanese Ministry of the Environment, and the study protocol was approved by the Committee on Medical Ethics of the Jichi Medical School (Approval No. 08-16). Informed consent was obtained from all individual subjects included in the study. All procedures performed in studies involving human subjects were in accordance with the ethical standards of the institutional and/or national research committee and with the 1964 Helsinki declaration and its later amendments or comparable ethical standard.

\section{Funding}

The research was financially supported by research grants from the Ministry of Health, Welfare and Labor and CREST-JST.

Received: 27 October 2015 Accepted: 26 May 2016

Published online: 24 June 2016

\section{References}

Agency for Toxic Substances and Disease Registry (2008) Cadmium toxicity. http://www.atsdr.cdc.gov/csem/cadmium/docs/cadmium.pdf

Bertin G, Averbeck D (2006) Cadmium: cellular effects, modifications of biomolecules, modulation of DNA repair and genotoxic consequences (a review). Biochimie 88:1549-1559

Cheng KC, Cahill DS, Kasai H, Nishimura S, Loeb LA (1992) 8-Hydroxyguanine, an abundant form of oxidative DNA damage, causes $\mathrm{G}-\mathrm{T}$ and $\mathrm{A}-\mathrm{C}$ substitutions. J Biol Chem 267:166-172

Cuypers A, Plusquin M, Remans T, Jozefczak M, Keunen E, Gielen H, Opdenakker K, Nair AR, Munters E, Artois TJ, Nawrot T, Vangronsveld J, Smeets K (2010) Cadmium stress: an oxidative challenge. Biometals 23:927-940

Davies KJ, Quintanilha AT, Brooks GA, Packer L (1982) Free radicals and tissue damage produced by exercise. Biochem Biophys Res Commun 107:1198-1205

Engström B, Nordberg GF (1979) Factors influencing absorption and retention of oral $109 \mathrm{Cd}$ in mice: age, pretreatment and subsequent treatment with non-radioactive cadmium. Acta Pharmacol Toxicol 45:315-324

Engström KS, Vahter M, Johansson G, Lindh CH, Teichert F, Singh R, Kippler M, Nermell B, Raqib R, Strömberg U, Broberg K (2010) Chronic exposure to cadmium and arsenic strongly influences concentrations of 8-0xo-7,8dihydro-2'-deoxyguanosine in urine. Free Radic Biol Med 48:1211-1217

Ercal N, Gurer-Orhan H, Aykin-Burns N (2001) Toxic metals and oxidative stress part I: mechanisms involved in metal-induced oxidative damage. Curr Top Med Chem 1:529-539

Flora SJ, Mittal M, Mehta A (2008) Heavy metal induced oxidative stress \& its possible reversal by chelation therapy. Indian J Med Res 128:501-523

Flora G, Gupta D, Tiwari A (2012) Toxicity of lead: a review with recent updates. Interdiscip Toxicol 5:47-58

Horiguchi H, Oguma E, Sasaki S, Miyamoto K, Ikeda Y, Machida M, Kayama F (2004a) Dietary exposure to cadmium at close to the current provisional tolerable weekly intake does not affect renal function among female Japanese farmers. Environ Res 95:20-31 
Horiguchi H, Oguma E, Sasaki S, Miyamoto K, Ikeda Y, Machida M, Kayama $\mathrm{F}$ (2004b) Comprehensive study of the effects of age, iron deficiency, diabetes mellitus, and cadmium burden on dietary cadmium absorption in cadmium-exposed female Japanese farmers. Toxicol Appl Pharmacol 196:114-123

Horiguchi H, Oguma E, Sasaki S, Miyamoto K, Ikeda Y, Machida M, Kayama $F$ (2005) Environmental exposure to cadmium at a level insufficient to induce renal tubular dysfunction does not affect bone density among female Japanese farmers. Environ Res 97:83-92

Irie M, Tamae K, Iwamoto-Tanaka N, Kasai H (2005) Occupational and lifestyle factors and urinary 8-hydroxydeoxyguanosine. Cancer Sci 96:600-606

Järup L (2002) Cadmium overload and toxicity. Nephrol Dial Transplant 17(suppl 2):35-39

Kasai H, Iwamoto-Tanaka N, Miyamoto T, Kawanami K, Kawanami S, Kido R, Ikeda M (2001) Life style and urinary 8-hydroxydeoxyguanosine, a marker of oxidative dna damage: effects of exercise, working conditions, meat intake, body mass index, and smoking. Jpn J Cancer Res 92:9-15

Kobayashi S, Murakami K, Sasaki S, Okubo H, Hirota N, Notsu A, Fukui M, Date C (2011) Comparison of relative validity of food group intakes estimated by comprehensive and brief-type self-administered diet history questionnaires against $16 \mathrm{~d}$ dietary records in Japanese adults. Public Health Nutr $14: 1200-1211$

Kohen R, Nyska A (2002) Oxidation of biological systems: oxidative stress phenomena, antioxidants, redox reactions, and methods for their quantification. Toxicol Pathol 30:620-650

Lauwerys RR, Bernard AM, Roels HA, Buchet JP (1994) Cadmium: exposure markers as predictors of nephrotoxic effects. Clin Chem 40:1391-1394

Lowry JA (2010) Oral chelation therapy for patients with lead poisoning. Report to World Health Organization. Kansas City, MO, USA: The Children's Mercy Hospitals and Clinics. http://www.who.int/selection_medicines/ committees/expert/18/applications/4_2 LeadOralChelators.pdf

McBride JM, Kraemer WJ, Triplett-McBride T, Sebastianelli W (1998) Effect of resistance exercise on free radical production. Med Sci Sports Exerc 30:67-72

Mecocci P, MacGarvey U, Kaufman AE, Koontz D, Shoffner JM, Wallace DC, Beal MF (1993) Oxidative damage to mitochondrial DNA shows marked agedependent increases in human brain. Ann Neurol 34:609-616

Mikhailova MV, Littlefield NA, Hass BS, Poirier LA, Chou MW (1997) Cadmiuminduced 8-hydroxydeoxyguanosine formation, DNA strand breaks and antioxidant enzyme activities in lymphoblastoid cells. Cancer Lett 115:141-148

Mizoue T, Kasai H, Kubo T, Tokunaga S (2006) Leanness, smoking, and enhanced oxidative DNA damage. Cancer Epidemiol Biomarkers Prev 15:582-585

Muller FL, Lustgarten MS, Jang Y, Richardson A, Van Remmen H (2007) Trends in oxidative aging theories. Free Radic Biol Med 43:477-503

Perth District Health Unit (2014) Lead and human health information for healthcare providers. http://www.pdhu.on.ca/wp-content/ uploads/2015/03/Lead-and-Human-Health-for-Healthcare-Providers.pdf
Pizzino G, Bitto A, Interdonato M, Galfo F, Irrera N, Mecchio A, Pallio G, Ramistella V, De Luca F, Minutoli L, Squadrito F, Altavilla D (2014) Oxidative stress and DNA repair and detoxification gene expression in adolescents exposed to heavy metals living in the Milazzo-Valle del Mela area (Sicily, Italy). Redox Biol 21:686-693

Poljsak B, Šuput D, Milisav I (2013) Achieving the balance between ROS and antioxidants: when to use the synthetic antioxidants. Oxid Med Cell Longev 2013:956792

Saito K, Aoki H, Fujiwara N, Goto M, Tomiyama C, Iwasa Y (2013) Association of urinary $8-\mathrm{OHdG}$ with lifestyle and body composition in elderly natural disaster victims living in emergency temporary housing. Environ Health Prev Med 18:72-77

Sakano N, Wang DH, Takahashi N, Wang B, Sauriasari R, Kanbara S, Sato Y, Takigawa T, Takaki J, Ogino K (2009) Oxidative stress biomarkers and lifestyles in Japanese healthy people. J Clin Biochem Nutr 44:185-195

Sasaki S, Yanagibori R, Amano K (1998) Self-administered diet history questionnaire developed for health education: a relative validation of the test-version by comparison with 3-day diet record in women. J Epidemiol 8:203-215

Shimoi K, Kasai H, Yokota N, Toyokuni S, Kinae N (2002) Comparison between high-performance liquid chromatography and enzyme-linked immunosorbent assay for the determination of 8-hydroxy-2'-deoxyguanosine in human urine. Cancer Epidemiol Biomarkers Prev 11:767-770

Szostak J, Laurant P (2011) The forgotten face of regular physical exercise: a 'natural' anti-atherogenic activity. Clin Sci (Lond) 121:91-106

Takahashi M, Miyashita M, Park JH, Sakamoto S, Suzuki K (2015) Effects of breaking sitting by standing and acute exercise on postprandial oxidative stress. Asian J Sports Med 6:e24902

Tamae K, Kawai K, Yamasaki S, Kawanami K, Ikeda M, Takahashi K, Miyamoto T, Kato N, Kasai H (2009) Effect of age, smoking and other lifestyle factors on urinary 7-methylguanine and 8-hydroxydeoxyguanosine. Cancer Sci 100:715-721

Thosar SS, Johnson BD, Johnston JD, Wallace JP (2012) Sitting and endothelial dysfunction: the role of shear stress. Med Sci Monit 18:RA173-180

Valavanidis A, Vlachogianni T, Fiotakis C (2009) 8-hydroxy-2'-deoxyguanosine (8-OHdG): a critical biomarker of oxidative stress and carcinogenesis. Environ Sci Health C Environ Carcinog Ecotoxicol Rev 27:120-139

Wilmot EG, Edwardson CL, Achana FA, Davies MJ, Gorely T, Gray LJ, Khunti K, Yates T, Biddle SJ (2012) Sedentary time in adults and the association with diabetes, cardiovascular disease and death: systematic review and metaanalysis. Diabetologia 55:2895-2905

Witherell HL, Hiatt RA, Replogle M, Parsonnet J (1998) Helicobacter pylori infection and urinary excretion of 8-hydroxy-2-deoxyguanosine, an oxidative DNA adduct. Cancer Epidemiol Biomarkers Prev 7:91-96

Wolf Fl, Fasanella S, Tedesco B, Cavallini G, Donati A, Bergamini E, Cittadini A (2005) Peripheral lymphocyte 8-OHdG levels correlate with age-associated increase of tissue oxidative DNA damage in Sprague-Dawley rats. Protective effects of caloric restriction. Exp Gerontol 40:181-188

\section{Submit your manuscript to a SpringerOpen ${ }^{\odot}$ journal and benefit from:}

- Convenient online submission

- Rigorous peer review

- Immediate publication on acceptance

- Open access: articles freely available online

- High visibility within the field

- Retaining the copyright to your article

Submit your next manuscript at springeropen.com 